\title{
Determination of frequency of specified structural congenital anomalies and the pattern of determinants affecting congenital malformations in prenatally diagnosed fetal anomaly cases before 20 weeks
}

\author{
Nishi Sood*, Manish Thakur
}

Department of Gynecology, Indra Gandhi Medical College, Shimla, Himachal Pradesh, India

\author{
Received: 12 October 2017 \\ Accepted: 08 November 2017 \\ *Correspondence: \\ Dr. Nishi Sood, \\ E-mail: nishi5644@gmail.com
}

Copyright: () the author(s), publisher and licensee Medip Academy. This is an open-access article distributed under the terms of the Creative Commons Attribution Non-Commercial License, which permits unrestricted non-commercial use, distribution, and reproduction in any medium, provided the original work is properly cited.

\begin{abstract}
Background: Congenital anomalies accounts for $8-15 \%$ of perinatal deaths and $13-16 \%$ of neonatal deaths in India. The aim of this study was to determine frequency of specified structural congenital anomalies and the pattern of determinants affecting congenital malformations in prenatally diagnosed fetal anomaly cases before 20 weeks

Methods: The present study was conducted at Kamla Nehru State Hospital for Mother and Child, Indira Gandhi Medical College, Shimla. During the study period, all pregnant women with prenatally diagnosed fetal anomaly before 20 weeks, reporting to the Department of OBG, were enrolled for this non-interventional prospective observational study. The observations were analysed on a statistical basis in structured data collection form.

Results: Congenital malformations were significantly more common in the age groups of 20-30 years, of low socioeconomic status, vegetarians and who were non-compliant regarding folic acid intake. The majority of women bearing malformed foetuses came from areas at altitude of 500-2000 meters. $33.33 \%$ of foetuses had amniotic fluid abnormalities. $83.33 \%$ of the foetuses had a single malformation. Central nervous system was the most common system involved $(61.90 \%)$ out of which neural tube defects $(76.91 \%)$ were commonest. $11.9 \%$ malformations were of the gastrointestinal tract out of which majority $(60 \%)$ were omphalocele. $4.76 \%$ of the total malformations were of the musculoskeletal system. $4.76 \%$ malformations involved the genito-urinary tract and $2.38 \%$ of the total malformations were of the cardiovascular system and craniofascial anomalies.

Conclusions: Early detection of major malformation during pregnancy helps in reducing the high morbidity and mortality of neonates due to congenital malformations because of termination of pregnancy. The commonest system found to be affected was central nervous system followed by gastro-intestinal system. Food fortification with folates and vitamin B12 is the need of the hour.
\end{abstract}

Keywords: Medical termination of pregnancy, Structural malformations, Twenty weeks

\section{INTRODUCTION}

India is undergoing an epidemiological transition. Communicable diseases are on the decline while noncommunicable, chronic and genetic diseases threaten to be a public health problem in India. One such group of disorders is congenital malformations. ${ }^{1}$ The term congenital malformation should be confined to structural defects at birth and the term congenital anomaly being used to include all biochemical, structural and functional disorders present at birth. Congenital malformations rank as the third most frequent cause of perinatal mortality in India. $^{2}$ Congenital anomalies accounts for $8-15 \%$ of perinatal deaths and $13-16 \%$ of neonatal deaths in India. ${ }^{3,4}$ Population and hospital-based studies from different parts of India show that $2.5 \%$ of new-borns have 
a birth defect. In the whole of North India, neural tube defects or spina bifida are the most common birth defects, the highest frequency being observed in Punjab (1 in 116 births). ${ }^{5}$ Congenital heart defects are the most common birth defects worldwide. ${ }^{6}$ Birth defects can be caused by single gene defects, chromosomal disorders, multifactorial inheritance, environmental teratogens, micronutrient deficiencies and maternal infectious diseases such as syphilis and rubella. Maternal illnesses like diabetes mellitus, iodine and folic acid deficiency are also known causes of birth defects. Exposure to certain medicines, recreational drugs and high doses of radiation are other factors that cause birth defects. Most birth defects are preventable by public health approaches. ${ }^{7}$ The shock of any prenatal diagnosis of fetal abnormality makes it hard for women to take in the information that they need to assimilate to make potentially life-changing decisions. $^{8}$ In India, the provision of termination of pregnancy is available under the M.T.P. (Medical Termination of Pregnancy) Act $1971 .{ }^{9}$ In Indian settings and outside India also, published data on detection of major congenital malformations before twenty weeks of gestation is seriously lacking. This is important to know because most of the studies regarding congenital malformations have focussed on new-born babies or later. Hence incidence of actual congenital malformations may be under reported as majority of these subgroup of pregnancies are aborted with second trimester MTP being legal in India.

\section{METHODS}

The present study was conducted at Kamla Nehru State Hospital for Mother and Child, Indira Gandhi Medical College, Shimla over one-year period. During the study period, all pregnant women with prenatally diagnosed fetal anomaly before 20 weeks, reporting to the Department of OBG, were enrolled for this noninterventional prospective observational study. Multiple pregnancy and intrauterine fetal death were excluded from the study

Detailed history was taken regarding various obstetric risk factors in current and previous pregnancy which included family history, any previous history of babies born with malformations, along with history of maternal infectious diseases such as syphilis and rubella, maternal illnesses like diabetes mellitus, conditions such as iodine and folic acid deficiency and exposure to certain medicines and recreational drugs including alcohol, tobacco and high doses of radiation. Baseline routine investigation of pregnancy was done in all cases. Patients were also screened for TORCH group of infections. Ultrasound findings and relevant biochemical findings were documented for each patient.

Ultrasound screening for fetal anomalies was done between 16 weeks 1 day and 18 weeks 6 days. If an anomaly was detected during the anomaly scan, pregnant women were informed of the findings to enable them to make an informed choice as to whether they wish to continue with the pregnancy or have a termination of pregnancy. Imaging studies like $2 \mathrm{D}$ echo, CT and MRI were offered in special cases.

Screening for chromosomal anomalies was also done in patients with family history of congenital anomaly, previous history of fetal anomaly, previous ultrasound showing fetal anomaly and maternal age $>35$ years. If these tests showed increased chance of having a baby with chromosomal abnormality, then these subjects were offered Chorionic villous sampling or Amniocentesis after counselling. In the presence of lethal or severely disabling anomalies, if future parents required the termination of pregnancy, consent was taken as per MTP Act and the termination of pregnancy done. Following delivery, fetus and placenta were examined grossly for congenital anomaly. Fetal autopsy was not done due to non-availability of pathological autopsy in the institute and associated ethical issues. Significance of difference was analysed using unpaired student $t$ test. Statistical analysis was done using statistical software Epi info version 7 and $p$ value $<0.05$ was considered significant.

\section{RESULTS}

The following observations were made during this study:

\section{Age of mother}

It was observed that out of 42 malformed fetuses, 18 $(42.85 \%)$ fetuses were born to women in the age group 20-25 years, $12(28.57 \%)$ fetuses were born to women in the age group 25-30 years, $10(23.8 \%)$ fetuses to women $>30$ years of age and two $(4.76 \%)$ fetuses were born to women $<20$ years of age (Table 1). The incidence of congenital malformations was significantly higher in the age group 20-30 years as compared to other age groups as this is the peak reproductive age.

\section{Maternal education}

Out of total 42 malformed fetuses, 5 (11.91\%) were born to mothers who were illiterate or with education level less than matric, while $37(88.09 \%)$ mothers whose education level was above matric had malformed fetuses. This number was statistically significant when compared with the less educated subjects $(\mathrm{p}<0.05)$ (Table 1$)$.

\section{Socioeconomic status}

The socioeconomic status of patients was analysed according to the modified Kuppuswamy scale. ${ }^{10}$

Five $(11.91 \%)$ malformed fetuses were born to mothers in class I, four $(9.52 \%)$ fetuses were born to mothers in class II while $33(78.52 \%)$, were born to mothers in class III, IV and V. This shows that majority of mothers with malformed fetuses belonged to lower socioeconomic 
class. This difference was statistically significant $(\mathrm{p}<0.01)$ (Table 1).

\section{Diet}

Out of 42 malformed fetuses, 26 (61.9\%) had vegetarian mothers. Non-vegetarian mothers had lesser malformations, but this difference was not statistically significant $(\mathrm{p}>0.05)$ (Table 1$)$.

Table 1: Socio demographic variables in anomaly positive cases $(\mathrm{N}=42)$.

\begin{tabular}{|c|c|c|c|c|}
\hline Variables & Category & Numbers & $\%$ & P value \\
\hline \multirow{4}{*}{$\begin{array}{l}\text { Age } \\
\text { group }\end{array}$} & $<20$ & 02 & 4.76 & \multirow{4}{*}{$(\mathrm{p}<0.05)$} \\
\hline & $20-25$ & 18 & 42.85 & \\
\hline & $>25-30$ & 12 & 28.57 & \\
\hline & $>30$ & 10 & 23.80 & \\
\hline \multirow[t]{2}{*}{ Literacy } & $\begin{array}{l}\text { Illiterate or } \\
\text { below } \\
\text { matric }\end{array}$ & 5 & 11.91 & $(\mathrm{p}<0.05)$ \\
\hline & $\begin{array}{l}\text { matric and } \\
\text { above }\end{array}$ & 37 & 88.09 & \\
\hline \multirow{5}{*}{$\begin{array}{l}\text { Socio } \\
\text { economic } \\
\text { status }\end{array}$} & I (upper) & 05 & 11.90 & $(\mathrm{p}<0.01)$ \\
\hline & $\begin{array}{l}\text { II (upper } \\
\text { middle) }\end{array}$ & 04 & 9.52 & \\
\hline & $\begin{array}{l}\text { III (lower } \\
\text { middle) }\end{array}$ & 09 & 21.42 & \\
\hline & $\begin{array}{l}\text { IV (upper } \\
\text { lower) }\end{array}$ & 19 & 45.23 & \\
\hline & V (lower) & 05 & 11.90 & \\
\hline \multirow[b]{2}{*}{ Diet } & Vegetarian & 26 & 61.90 & \\
\hline & $\begin{array}{l}\text { Non- } \\
\text { vegetarian }\end{array}$ & 16 & 38.09 & \\
\hline
\end{tabular}

\section{Gravidity}

18 (42.85\%) malformed fetuses were born to primigravidae, while $24(57.14 \%)$ were born to multigravida. This difference was statistically significant $(\mathrm{p}<0.01)$ (Table 2).

\section{Previous history of malformed baby}

It was observed that two $(8.33 \%)$ out of 24 multigravida mothers with malformed fetuses had previous history of malformed baby. This association was not found to be statistically significant $(\mathrm{p}>0.05)$ (Table 2$)$.

\section{Family history of anomalies}

Mothers of two (4.76\%) malformed fetuses out of total of 42 had a family history of anomalies. The correlation was however not significant statistically ( $\mathrm{p}>0.05)$ (Table 2$)$.

\section{History of abortion}

Out of 24 multigravida mothers with malformed fetuses, three $(12.5 \%)$ mothers gave history of abortion. This correlation was not statistically significant $(\mathrm{p}>0.05)$.
Table 2: High risk factors associated with congenital malformations.

\begin{tabular}{|c|c|c|c|}
\hline Variables & Category & $\begin{array}{l}\text { Numbers } \\
(\%)\end{array}$ & $\mathbf{P}$ value \\
\hline \multirow{2}{*}{$\begin{array}{l}\text { Parity } \\
N=42\end{array}$} & Primigravida & $18(42.8 \%)$ & \multirow{2}{*}{$(\mathrm{p}<0.01)$} \\
\hline & Multigravida & $24(57.2 \%)$ & \\
\hline \multirow{2}{*}{$\begin{array}{l}\text { Previous history } \\
\text { of malformed } \\
\text { baby } N=24\end{array}$} & Present & $2(8.33 \%)$ & \multirow[b]{2}{*}{$(p>0.05)$} \\
\hline & Absent & $22(91.66 \%)$ & \\
\hline \multirow{2}{*}{$\begin{array}{l}\text { Family history } \\
\text { of anomalies } \\
\mathrm{N}=42\end{array}$} & Present & $2(4.76 \%)$ & \multirow[b]{2}{*}{$(\mathrm{p}>0.05)$} \\
\hline & Absent & $\begin{array}{l}40 \\
(95.23 \%)\end{array}$ & \\
\hline \multirow{2}{*}{$\begin{array}{l}\text { History of } \\
\text { abortion } \\
\mathrm{N}=24\end{array}$} & Present & $3(12.5 \%)$ & \multirow[b]{2}{*}{$(\mathrm{p}>0.05)$} \\
\hline & Absent & $21(87.5 \%)$ & \\
\hline \multirow{2}{*}{$\begin{array}{l}\text { Consanguineous } \\
\text { marriage } \\
\mathrm{N}=42\end{array}$} & Present & $1(2.38 \%)$ & \multirow[b]{2}{*}{$(\mathrm{p}>0.05)$} \\
\hline & Absent & $41(97.61 \%)$ & \\
\hline $\begin{array}{l}\text { History of folic } \\
\text { acid intake in } \\
\text { mother } \mathrm{N}=42\end{array}$ & Absent & $\begin{array}{l}20 \\
(47.61 \%)\end{array}$ & \multirow{5}{*}{$(\mathrm{p}<0.0)$} \\
\hline $\begin{array}{l}\text { History of } \\
\text { teratogenic drug } \\
\text { intake in mother } \\
\mathrm{N}=42\end{array}$ & Present & $3(11.90 \%)$ & \\
\hline \multirow{3}{*}{$\begin{array}{l}\text { Amniotic fluid } \\
\mathrm{N}=42\end{array}$} & $\begin{array}{l}\text { Poly- } \\
\text { hydramnios }\end{array}$ & $9(21.42 \%)$ & \\
\hline & $\begin{array}{l}\text { Oligo- } \\
\text { hydramnios } \\
\text { /anhydramnios }\end{array}$ & $5(11.90 \%)$ & \\
\hline & Normal & $\begin{array}{l}28 \\
(66.66 \%)\end{array}$ & \\
\hline $\begin{array}{l}\text { History of } \\
\text { smoking in } \\
\text { mother } \mathrm{N}=42\end{array}$ & Present & $2(4.76 \%)$ & \\
\hline $\begin{array}{l}\text { History of } \\
\text { alcohol intake in } \\
\text { mother } \mathrm{N}=42\end{array}$ & Present & $1(2.38 \%)$ & \\
\hline $\begin{array}{l}\text { Maternal overt } \\
\text { diabetes } N=42\end{array}$ & Present & $2(4.76 \%)$ & \\
\hline $\begin{array}{l}\text { Intrauterine } \\
\text { infections } \\
\text { (TORCH, } \\
\text { Syphilis, HIV) }\end{array}$ & Present & Nil & \\
\hline
\end{tabular}

\section{Consanguineous marriage}

It was observed that out of 42 mothers with malformed fetuses, one $(2.38 \%)$ fetus was born out of consanguineous marriage as compared to 41 malformed fetuses born out of non-consanguineous marriages.

The correlation was also not statistically significant ( $>0.05)$.

\section{History of folic acid intake in mother}

As per Table 2, $20(47.6 \%)$ mothers with malformed fetuses denied history of folic acid intake during early pregnancy as majority came for antenatal check-up in late first trimester. 


\section{History of teratogenic drug intake in mother}

Mothers of three fetuses had history of taking antiepileptic drugs (phenytoin and carbamazepine) which are potentially teratogenic. But it was not statistically significant $(\mathrm{p}>0.05)$ (Table 2).

\section{Amniotic fluid}

It was observed that out of 42 malformed fetuses, 14 fetuses $(33.33 \%)$ had either increased or decreased amniotic fluid as compared to 28 fetuses (66.66\%) with normal amniotic fluid. This difference was statistically significant $(\mathrm{p}<0.01)$.

Oligohydramnios or anhydramnios was associated with five malformed fetuses $(11.90 \%)$. Polyhydramnios was seen in nine $(21.42 \%)$ mothers with malformed fetuses (Table 2).

\section{History of smoking in mother}

Only two mothers $(4.76 \%)$ with malformed fetuses had history of smoking as compared to 40 mothers who were not smokers (Table 2).

\section{History of alcohol intake in mother}

As Table 2 depicts, only one mother (2.38\%) with malformed fetus gave history of alcohol intake.

\section{Maternal overt diabetes}

Table 2 shows that out of 42 subjects with malformed fetuses, only two $(4.76 \%)$ had overt diabetes (controlled and conceived on Metformin). However, the number of diabetic mothers with malformed fetuses was not statistically significant ( $\mathrm{p}>0.05)$.

Intrauterine Infections Out of the 42 subjects with malformed babies, all the subjects were screened for syphllis and HIV and found to be negative whereas 24 subjects were screened for TORCH group of infections and none of them had any evidence of infection (Table 2).

\section{System involvement}

Table 3 depicts the involvement of different systems which were observed in the present study. It was seen that $61.9 \%$ of malformed fetuses had CNS anomalies. Gastrointestinal malformations were the second most common anomalies accounting for $11.9 \%$. This was followed by respiratory system malformations (7.14\%). musculoskeletal, genitourinary and craniofacial system malformations contributed $4.76 \%$ of anomalies each. Cardiovascular and others (hydrops fetalis with cystic hygroma) anomalies affected only $2.38 \%$ of malformed fetuses each.
Table 3: System involvement.

\begin{tabular}{|c|c|c|c|}
\hline Organ system & $\begin{array}{l}\text { Total } \\
(\mathbf{N})\end{array}$ & Anomaly & $\begin{array}{l}\text { Number } \\
(\%)\end{array}$ \\
\hline \multirow{8}{*}{ CNS } & \multirow{8}{*}{26} & Anencephaly & $10(38.46)$ \\
\hline & & Spinabifida & $5(19.23)$ \\
\hline & & Meningomyelocele & $3(11.53)$ \\
\hline & & Hydrocephalus & $3(11.53)$ \\
\hline & & Encephalocele & $2(7.69)$ \\
\hline & & $\begin{array}{l}\text { Sacrococcygeal } \\
\text { teratoma }\end{array}$ & $1(2.38)$ \\
\hline & & $\begin{array}{l}\text { Hypoplastic } \\
\text { cereberal } \\
\text { hemispheres }\end{array}$ & $1(2.38)$ \\
\hline & & Holoprosencephaly & $1(2.38)$ \\
\hline \multirow{2}{*}{ Gastrointestinal } & \multirow{2}{*}{5} & Omphalocele & $3(60)$ \\
\hline & & Gastroschisis & $2(40)$ \\
\hline \multirow[t]{2}{*}{ Respiratory } & \multirow[t]{2}{*}{3} & $\begin{array}{l}\text { Congenital } \\
\text { diaphragmatic } \\
\text { hernia }\end{array}$ & $2(66.66)$ \\
\hline & & $\begin{array}{l}\text { Pulmonary } \\
\text { hypoplasia }\end{array}$ & $1(33.33)$ \\
\hline \multirow[t]{2}{*}{ Musculoskeletal } & \multirow[t]{2}{*}{2} & $\begin{array}{l}\text { Thanatophoric } \\
\text { dysplasia }\end{array}$ & $1(50)$ \\
\hline & & Rhizomelia & $1(50)$ \\
\hline Genitourinary & 2 & Absent kidneys & $2(100)$ \\
\hline \multirow{2}{*}{ Craniofacial } & \multirow{2}{*}{2} & Cleft lip & $1(50)$ \\
\hline & & Cleft palate & $1(50)$ \\
\hline Cardiovascular & 1 & Single ventricle & $1(100)$ \\
\hline Others & 1 & $\begin{array}{l}\text { Hydrops fetalis with } \\
\text { cystic hygroma }\end{array}$ & $1(100)$ \\
\hline Total & 42 & & \\
\hline
\end{tabular}

Out of 26 fetuses with central nervous system malformations, $20(76.91 \%)$ had neural tube defects and three $(11.53 \%)$ had hydrocephalus. There was one $(2.38 \%)$ case each with sacrococcygeal teratoma, hypoplastic cerebellar hemispheres and holoprosencephaly. The neural tube defects were significantly more common than the other malformations ( $p<0.01$ ). Out of 20 fetuses with neural tube defects, 10 $(38.46 \%)$ had anencephaly, five $(19.23 \%)$ had spina bifida, three $(11.53 \%)$ had meningomyelocele and two (7.69\%) had encephalocele.

Gastrointestinal anomalies seen in five fetuses were, three cases of omphalocele and two cases of gastroschisis. Out of two fetuses with musculoskeletal malformations, one had thanatophoric dysplasia and the other had rhizomelia. In respiratory system anomalies two fetuses had congenital diaphragmatic hernia and one was a case of pulmonary hypoplasia. Both fetuses of genitourinary malformations was in the form of absent kidneys. Craniofacial malformations were in the form of cleft lip in one fetus and cleft palate in the other. Cardiovascular malformation was found in a single fetus who was diagnosed with single ventricle. One of the fetus had hydrops fetalis with cystic hygroma.

Out of 42 malformed fetuses, $35(83.33 \%)$ had a single malformation defect and seven $(16.66 \%)$ fetuses had 
multiple defects. This difference was statistically significant $(\mathrm{p}<0.01)$.

\section{Altitude}

Out of 42 malformed fetuses, four $(9.52 \%)$ were born to women coming from altitude $<500$ meters, and 35 $(83.33 \%)$ fetuses were born to women coming from areas with altitude of 500-2000 meters. Three fetuses (7.14\%) were born to women from altitude $>2000$ meters. The majority of women (35/42) with malformed fetuses came from areas at altitude of 500-2000 meters and commonest anomaly found in them was in CNS while none of the three patients who came from $>2000$ meters had any CNS anomaly.

Table 4: Malformations at high altitude.

\begin{tabular}{|c|c|c|}
\hline Study & $\begin{array}{l}\text { Altitude } \\
\text { (meters) }\end{array}$ & $\begin{array}{l}\text { Malformations at } \\
\text { high altitude }\end{array}$ \\
\hline Castilla EE & $>2000$ & $\begin{array}{l}\text { Cleft lip, microtia, } \\
\text { preauricular tag, } \\
\text { branchial arch } \\
\text { anomaly complex, } \\
\text { constriction band } \\
\text { complex and anal } \\
\text { atresia }\end{array}$ \\
\hline Grover N & $500-2000$ & CNS malformation \\
\hline Malla BK & $500-2000$ & CNS malformation \\
\hline Present study & $500-2000$ & CNS malformation \\
\hline
\end{tabular}

\section{DISCUSSION}

Congenital malformations are a common cause of perinatal mortality and morbidity. In the present one-year study, subjects with period of gestation less than twenty weeks with structurally malformed fetuses were taken as study group which came out to be 42 . All of these subjects opted for termination of pregnancies. There were 6100 deliveries in our institution during the same period and out of these, there were 86 fetuses with malformations who delivered at or near term. Thus, the incidence of congenital malformations in our institution was $1.3 \%$ in viable fetuses with most of them having major structural anomalies. This number could have been less had these malformations been detected earlier with the option of termination of pregnancy.

In the present study, congenital malformations were common in the age groups of $20-25$ years $(42.85 \%)$ and 25-30 years $(28.57 \%)$. This was comparable to studies by Taksande $\mathrm{A}$ et al and Sarkar $\mathrm{S}$ et al because this is the peak reproductive age in most of the societies. ${ }^{11,12}$

On the contrary, in the study by Shawky RM et al, anomalies were more common in the maternal age of $>35$ years. ${ }^{13}$ The pregnancies with extremes of maternal age are rare in our institute. In an effort to study this issue, a large sample that accurately reflects the entire obstetric population needs to be studied.

The majority of malformed fetuses were born to mothers with education level above matric (88.09\%). Only 5 were born to mothers who were illiterate or below matric level of education. Although it has been seen that illiterate mothers have more chances of giving birth to malformed babies, the probable reason for more malformed fetuses in higher educated subjects in the present study could be the high literacy rate of our state $(>90 \%)$ which resulted in greater awareness and early antenatal checkups with better early detection rate. ${ }^{14}$

The present study showed higher proportion of mothers with anomalous babies belonging to the lower socioeconomic group. Lower socioeconomic class may be an indirect determinant of congenital anomalies. This higher risk relates to a possible lack of access to sufficient, nutritious foods by pregnant women, an increased exposure to agents or factors such as infection and alcohol, or lack of access to healthcare and screening. ${ }^{15}$

$26(61.9 \%)$ mothers with malformed fetuses were vegetarian probably because of deficiency of vitamin B12 in vegetarian diet. But this difference was not statistically significant $(\mathrm{P}>0.05)$. Vegetarians have 4.4 times higher risk of low B12 concentrations and 3.0 times higher risk of hyperhomocysteinemia compared to those who ate non-vegetarian foods frequently. ${ }^{16}$

It was observed that $42.85 \%$ fetuses were born to primigravida while $53.15 \%$ were born to multigravida. This incidence of malformed fetuses was in contrast to the study by Desai et al and Perveen $F$ et al where incidence of malformation was more in Primigravida. ${ }^{17,18}$

Present result is consistent with the finding of study by Bhalerao et al, which indicates a positive correlation between the birth order and the incidence of congenital anomalies. $^{19}$

$47.61 \%$ of mothers with malformed fetuses had not taken folic acid in the present study. It was much more in comparison to the study by Singh A (19.29\%) and lower than that observed in the study by Shawky RM $(72.49 \%) .^{20,13}$ Folates are required for purine and pyrimidine synthesis and methylation reactions including methylation of Homocysteine to methionine. ${ }^{21}$

Primary prevention of birth defects by adequate periconceptional folic acid supplementation is a major public health opportunity and has wide implications in reducing both mortality and morbidity due to birth defects. $^{22}$ 
Table 5: Systems involved in different studies.

\begin{tabular}{|c|c|c|c|c|c|c|}
\hline Study & $\begin{array}{l}\text { Main system } \\
\text { involved }\end{array}$ & $\begin{array}{l}\% \text { of Central } \\
\text { nervous } \\
\text { system }\end{array}$ & $\begin{array}{l}\text { \% of Musculo } \\
\text { skeletal } \\
\text { system }\end{array}$ & $\begin{array}{l}\% \text { of Cardio } \\
\text { vascular } \\
\text { system }\end{array}$ & $\begin{array}{l}\% \text { of Gastro } \\
\text { intestinal } \\
\text { tract }\end{array}$ & $\begin{array}{l}\% \text { of } \\
\text { Genito } \\
\text { urinary tract }\end{array}$ \\
\hline Ronya et al & & 17.3 & & & 20.4 & 20.4 \\
\hline Balakumar K & $\mathrm{CNS}$ & 39.21 & 11.79 & 5.25 & & \\
\hline Malla BK & CNS & 40 & 18.67 & & 17.3 & 6.77 \\
\hline Perveen F et al & $\mathrm{CNS}$ & 65.8 & 17.1 & & & \\
\hline Taksande A et al & CVS & 09.14 & 21.95 & 23.17 & 8.53 & 13.41 \\
\hline Shawky RM & CNS & 55 & 18 & 1.3 & 4 & 38 \\
\hline Sarkar S et al & $\begin{array}{l}\text { Musculoskeletal } \\
\text { system }\end{array}$ & 11.20 & 33.2 & 9.1 & 15 & 10.5 \\
\hline Francine $\mathrm{R}$ et al & CVS & 08.40 & 08.40 & 16.66 & 8.4 & 8.4 \\
\hline Singh A et al & $\begin{array}{l}\text { Genitourinary } \\
\text { system }\end{array}$ & 12.8 & 15 & 27.1 & 23.1 & 20.9 \\
\hline Bhalerao A et al & $\begin{array}{l}\text { Musculoskeletal } \\
\text { system }\end{array}$ & 25 & 36.90 & 25 & 16.6 & 10.7 \\
\hline Present study & $\begin{array}{l}\text { Central nervous } \\
\text { system }\end{array}$ & 61.90 & 4.76 & 2.38 & 11.90 & 4.76 \\
\hline
\end{tabular}

$11.9 \%$ of mothers of malformed fetuses had history of teratogenic drug intake (antiepileptic drugs - phenytoin and carbamazepine) which was comparable to the study by Singh A (15.62\%) and lower than that observed in a study by Shawky RM $(36.32 \%) .^{20,13}$ Crucial morphogenetic processes during the blastogenesis period, which extends throughout the first 4 weeks of development, can be altered by teratogenic agent and result in structural abnormalities. ${ }^{23}$ It can be prevented by periconceptional counselling and if at all the drug has to be taken, then option of changing to more safer drug therapy and in lesser dose should be considered.

In the present study polyhydramnios was present in $21.42 \%$ of malformed fetuses. It was comparable to the study by Perveen F et al (22.9\%) but was higher than that observed in a study by Shawky RM (10.79\%). ${ }^{18,13}$ Similarly oligohydramnios was seen in $11.9 \%$ of malformed foetuses in the present study which was comparable to the study by Shawky RM $(9.81 \%)$ but was lower than that observed in the study by Stoll $\mathrm{C}$ et al $(32.6 \%) .^{13,24}$

Fetal congenital anomalies and diabetes are common underlying causes of polyhydramnios. ${ }^{25}$ Moreover in all these studies, majority of subjects had neural tube defects which are associated with polyhydramnios. Most cases of severely decreased amniotic fluid volume beginning early in gestation are secondary to genitourinary anomalies. Anomalies of other organ systems, aneuploidy, and other genetic syndromes also have the potential to cause oligohydramnios indirectly. ${ }^{26}$

4.76\% mothers with malformed fetuses had diabetes in our study. It was comparable to the study by Perveen F et al $(5.26 \%)$ and slightly lower than the study by Shawky RM et al $(7.28 \%) .{ }^{18,13}$ The incidence of fetal structural defects caused by maternal pregestational diabetes is three- to fourfold higher than the non-diabetic pregnancy. Successful preconception counselling for women with diabetes mellitus and metabolic control will reduce birth defects and maternal morbidity. ${ }^{27}$

It was observed in the present study that $3(7.14 \%)$ out of 42 subjects with malformed fetuses had previous history of malformed baby. There was no significant difference between subjects with prior malformed fetuses and those without such history ( $>>0.05)$. Presence of family history of congenital anomalies was observed in $2.38 \%$ of subjects. It was relatively lower to that observed in the study by Perveen F et al $(5.26 \%){ }^{18}$ The present study observed that $19.04 \%$ had previous history of abortions which was lower than that observed in other studies like Perveen F et al (26.3\%), Shawky RM (32.37\%) and Singh A $(70.55 \%) .{ }^{18,13,20}$

$2(4.76 \%)$ mothers of malformed fetuses in the present study had history of smoking (active/passive) which was much lower than that observed in the study by Shawky RM (55.44\%). ${ }^{13}$ The possible explanation for this could be the fact that smoking is not commonly seen among women in this part of the country due to sociocultural factors. Similarly, only one mother $(2.38 \%)$ had history of alcohol intake. Alcohol consumption is not commonly seen among females due to sociocultural restraints prevailing in our society. The consumption of alcoholic beverages by a pregnant woman may cause numerable deleterious effects in the fetus constituting a severe clinical picture called fetal alcohol syndrome (FAS), or a group of more subtle cognitive and/or behavioral dysfunctions. $^{28}$

In the present study, only one case (2.38\%) of consanguineous marriage was observed. It was comparable to the study by Sarkar $\mathrm{S}$ et al $(0.69 \%) .{ }^{12}$ 
However higher proportion was seen in studies by Perveen F (44.74\%) and Francine R (41.66\%). ${ }^{18,29}$ The subjects in the present study were mostly Hindus and marriages in close relation are uncommon among Hindus due to socio-cultural factors.

The present study observed that $26 \quad(61.90 \%)$ malformations were of the central nervous system, out of which 20 were neural tube defects. CNS was the most common system affected by malformations in most of the studies as shown in Table 5. The frequency of central nervous system involvement varied from $9.14 \%$ in the study by Taksande A et al to $65.8 \%$ in the study by Perveen $\mathrm{F}$ et al, which was comparable to the present study. ${ }^{11,18}$ Main factors responsible are nutritional deficiency of vitamin B12, vitamin B6 and folate which results in hyperhomocysteinemia and neural tube defects. This may also be attributed to vegetarian diet and poverty. ${ }^{16}$ Another reason for higher frequency for CNS malformations could be higher detection rate of these malformations by first and second trimester ultrasounds

In the present study, $4.76 \%$ of the total malformations were of the musculoskeletal system. Musculoskeletal system was reported to be the commonest system involved in the studies by Sarkar S et al (33.2\%) and Bhalerao A et al (36.9\%). ${ }^{12,19}$ In most of the remaining studies, it was the second most common system involved. Most common anomaly of musculoskeletal system in most studies was congenital talipes equino varus.

The present study found that $11.9 \%$ malformations were of the gastrointestinal tract out of which majority $(60 \%)$ were omphalocele. In the study by Ronya et al, GIT was the most common system involved in malformations $(20.4 \%){ }^{30}$ The percentage of gastrointestinal anomalies has not changed over the past 15 years as shown by comparison with study by Grover $\mathrm{N}$ et al $(11.67 \%){ }^{31}$ However, tracheoesophageal fistula was the most common malformation in that study in contrast to omphalocele $(60 \%)$ in the present study. This discrepancy could be due to the fact that the subjects in the study by Grover $\mathrm{N}$ et al included even term pregnancies and neonates. ${ }^{31}$ Anomalies like tracheoesophageal fistulas are confirmed after birth and our study constituted malformed fetuses less than 20 weeks gestation.

The present study found that $4.76 \%$ malformations involved the genitourinary tract in the form of two cases of absent kidneys. In a study by Ronya $\mathrm{R}$ et al and Singh A et al, genitourinary tract was the most common system involved in anomalies. ${ }^{30,20}$ The involvement of the genitourinary tract in malformations is highly variable, with a low percentage in the study by Malla BK et al (1.6\%) to a higher one by Singh A et al (29\%). ${ }^{32,20}$ The basis for the combined involvement of genital and urinary systems is their common origin from intermediate mesoderm.

Table 5 shows that $2.38 \%$ of the total malformations in our study were of the cardiovascular system. However cardiovascular system was the most frequent system to be involved in anomalies in the studies by Taksande A et al $(23.17 \%)$ and Francine $\mathrm{R}$ et al (16.66\%). ${ }^{11,29}$ The percentage involvement of cardiovascular system in anomalies has increased from $9.1 \%$ in the study by Sarkar $\mathrm{S}$ et al to $27.1 \%$ in a study by Singh A et al. ${ }^{12,20}$ This can be attributed to increased detection of cardiac anomalies by use of better sophisticated diagnostic techniques like fetal echocardiography, incorporating four chamber views of the heart and use of Colour Doppler.

$35(83.33 \%)$ mothers had a single malformation while the rest had multiple malformations. This difference was statistically significant ( $p<0.01$ ). Multiple malformations may point towards presence of a fetal syndrome and therefore finding of any one anomaly on ultrasound indicates the need for a detailed scan of the fetus to rule out other anomalies.

Altitude as depicted in Table 4, CNS malformations was the most common congenital malformation observed in the present study and our institution is located in the altitude zone of 500-2000 metres. Findings in the present study were similar to the study by Grover $\mathrm{N}$ et al conducted at IGMC Shimla, fifteen years ago and the study by Malla BK conducted at Kathmandu. ${ }^{31,32}$ This comparability may be due to similar environmental factors operating in the Himalayan region. On the contrary, in a study by Castilla E et al, in South America, at a relatively higher zone of altitude of $>2000$ metres, lower risk of neural tube defects was reported. ${ }^{33}$ However, they reported a higher incidence of fetal anomalies, namely cleft lip, microtia, preauricular tag, branchial arch anomaly and anal atresia.

\section{CONCLUSION}

With the routine use of anomaly scan and biochemical screening, the detection rates of congenital anomalies has increased tremendously. Early detection of major malformation during early pregnancy helps in reducing the high morbidity and mortality of neonates due to congenital malformations because of early medical termination of pregnancy. In the present study the commonest system found to be affected was central nervous system followed by gastro-intestinal system. The policy of periconceptional folic acid supplementation was not very effective. Thus, there is a need of better IEC activities for proper implementation. Also, majority of present study population was vegetarian; hence food fortification with folates and vitamin B12 is the need of the hour. Apart from pre-pregnancy folic acid supplementation, early booking, regular antenatal visits and early prenatal diagnosis are need of the hour for early detections.

Funding: No funding sources Conflict of interest: None declared

Ethical approval: The study was approved by the Institutional Ethics Committee 


\section{REFERENCES}

1. Suresh S, Thangavel GU, Sujatha JA, Indrani S. Methodological issues in setting up a surveillance system for birth defects in India. Nat Med J India. 2005;18(5).

2. Park K. Park's Textbook of Preventive and Social Medicine, $21^{\text {st }}$ ed. Jabalpur: Bhanot Publishers; 2011:531.

3. Bhat BV, Ravikumara M. Perinatal mortality in IndiaNeed for introspection. Indian J Ma-tern Child Health. 1996;7:31-3.

4. Agarwal SS, Singh PS, Singh SS, Das V, Sharma A. Prevalence and spectrum of congenital malformations in a prospective study at a teaching hospital. Indian $\mathrm{J}$ Med Res. 1991;94: 413-9.

5. Kumar V, Singh AJ, Marwaha RK. An epidemiological study of congenital malformations in rural children. Swasth Hind. 1986;30(7):165.

6. WHO. Global health situations and projectionsestimates, Geneva: WHO Division of Epidemiological Surveillance and Health Situation and Trend Assessment; 1992.

7. WHO. Birth defects report. Geneva: WHO Sixty Third World Health Assembly Journal. 2015. Avaialable at http://apps.who.int/gb/ebwha/pdf_files/WHA63-

REC1/WHA63_REC1-en.pdf

8. Termination of pregnancy report. London: Royal College of Obstetricians and Gynaecologists; 2010. Available

at https://www.rcog.org.uk/globalassets/documents/guidel ines/terminationpregnancyreport18may2010.pdf

9. The Medical Termination of Pregnancy Act, 1971, India. Available at www.mohfw.nic.in/ index1.php

10. Mishra D, Singh HP. Kuppuswamy's socioeconomic status scale- A revision. Indian $\mathbf{J}$ Pediatr. 2003;70(3):273-4.

11. Taksande A, Vilhekar K, Chaturvedi P, Jani M. Congenital malformations at birth in Central India: a rural medical college hospital based data. Indian J Human Genetics. 2010;16(3):159-63.

12. Sarkar S, Patra C, Dasgupta MK. Prevalence of congenital anomalies in neonates and associated risk factors in a tertiary care hospital in Eastern India. J Clin Neonatol. 2013;2(3):131-4

13. Shawky RM, Sadik DI. Congenital malformations prevalent among Egyptian children and associated risk factors. Egyptian J Med Human Genetics. 2011;12(1):69-78

14. Kamble V, Patil S, Bhatia T, Thaware P, Mathur P. The epidemiological study of congenital anomalies and their possible risk factors in Navi Mumbai. Int $\mathbf{J}$ Reprod Contracept Obstet Gynecol. 2015;4(5):1396-9.

15. Christianoon RE, Van Den Berg BJ, Milkovich WF, Oechsli L. Incidence of congenital anomalies among white, black live births with long-term follow-up. J Public Health. 1981;71:1333-41.

16. Yajnik CS, Deshpande SS, Lubree HG, Naik SS, Bhat DS, Uradey BS. Vitamin B12 deficiency and hyperhomocysteinemia in rural and urban Indians. J Assoc Pediatr India. 2006;54:775-82.

17. Desai NA. Congenital anomalies: a prospective study at a teaching hospital. Indian J Pediatr. 1991;94:413-9.
18. Perveen F, Tyaab S. Frequency and pattern of distribution of congenital anomalies in the newborn and associated maternal risk factors. J Coll Physicians Surg Pak. 2007;17(6):340-3.

19. Bhalerao A, Garg R. Pattern of Congenital anomalies at birth. Int $\mathrm{J}$ Obstet Gynaecol Res (IJOGR). 2016;3(7):420-6.

20. Singh A, Sinha S. Risk factors of congenital malformations in North India: a case-control study. J Postgraduate Med Education Res.2016;50(2):59-63.

21. Daly LE, Kirke PN, Molloy A, Weir DG, Scott JM. Folate levels and neural tube defects implications for prevention. JAMA. 1995;274(21):1698-701.

22. Gabbe, Steven G. Obstetrics, $5^{\text {th }}$ ed. Philadelphia: Elsevier/Saunders; 2012:986-7.

23. Holmes LB, Harvey EA, Coull BA. The teratogenicity of anticonvulsant drugs. New England J Med. 2001;344:1132-8.

24. Stoll C, Alembik Y, Roth MP, Dott B. Study of 224 cases of oligohydramnios and congenital malformations in a series of 225,669 consecutive births. Public Health Genomics. 1998;1:71-7.

25. Stoll C, Alembik Y, Dott B. Study of 156 Cases of polyhydramnios and congenital malformations in a series of 118,265 consecutive births. Am J Obstet Gynecol. 1991;165(3):586-90.

26. Martínez-Frías ML, Bermejo E, Rodríguez-Pinilla E, Frias JL. Maternal and fetal factors related to abnormal amniotic fluid. J Perinatol. 1999;19(7).

27. Chen CP. Congenital malformations associated with maternal diabetes. Taiwanese J Obstet Gynecol. 2005;44(1):1-7.

28. Grewal J, Carmichael SL, Ma C, Lammer EJ, Shaw GM. Maternal periconceptional smoking and alcohol consumption and risk for select congenital anomalies. Birth Defects Research Part A: Clinical and Molecular Teratology. 2008;82(7):519-26.

29. Francine R, Pascale S, Aline H. Congenital anomalies: prevalence and risk factors. Univ J Public Health. 2014;2(2):58-63.

30. Ronya R, Gupta D, Ghosh SK, Narang R, Jain KB. Spectrum of congenital surgical malformations in newborns. J India Med Assoc. 2002;100(9):565-6.

31. Grover N. Congenital malformations in Shimla. Indian J Pediatr. 2000;67(4):249-51.

32. Malla BK. One year review study of congenital anatomical malformation at birth in maternity hospital (Prasutigriha), Thapathali, Kathmandu. Kathmandu Univ Med J. 2007;5(4):557-60.

33. Castilla E, Lopez-Camelo J, Campana H. Altitude as a risk factor for congenital anomalies. Am J Med Genet. 1999;86(1):9-14.

Cite this article as: Sood N, Thakur M.

Determination of frequency of specified structural congenital anomalies and the pattern of determinants affecting congenital malformations in prenatally diagnosed fetal anomaly cases before 20 weeks. Int J Reprod Contracept Obstet Gynecol 2017;6:5572-9. 